\title{
Biotic Potential and Reproductive Parameters of Spodoptera frugiperda (J. E. Smith, 1797) (Lepidoptera: Noctuidae)
}

\author{
Débora G. Montezano ${ }^{1}$, Alexandre Specht ${ }^{2}$, Daniel R. Sosa-Gómez ${ }^{3}$, Vânia F. Roque-Specht ${ }^{4}$, \\ Juaci V. Malaquias ${ }^{2}$, Silvana V. Paula-Moraes ${ }^{5}$, Julie A. Peterson ${ }^{6} \&$ Thomas E. Hunt $^{7}$ \\ ${ }^{1}$ Department of Entomology, University of Nebraska-Lincoln, Lincoln, NE, USA \\ ${ }^{2}$ Embrapa Cerrados, Planaltina, DF, Brazil \\ ${ }^{3}$ Embrapa Soja, Londrina, PR, Brazil \\ ${ }^{4}$ Faculdade UnB Planaltina, Universidade de Brasília, Planaltina, DF, Brazil \\ ${ }^{5}$ West Florida Research and Education Center, Entomology \& Nematology Department, University of Florida, \\ Jay, FL, USA \\ ${ }^{6}$ West Central Research \& Extension Center, Department of Entomology, University of Nebraska-Lincoln, \\ North Platte, NE, USA \\ ${ }^{7}$ Haskell Agricultural Laboratory, Department of Entomology, University of Nebraska-Lincoln, Concord, NE, \\ USA
}

Correspondence: Débora G. Montezano, Department of Entomology, University of Nebraska-Lincoln, Lincoln, Nebraska, 68583-0816, USA. Tel: 1-402-430-2395. E-mail: deiagm@gmail.com

Received: May 18, 2019

doi:10.5539/jas.v11n13p240
Accepted: June 30, 2019 Online Published: August 15, 2019

URL: https://doi.org/10.5539/jas.v11n13p240

\begin{abstract}
The fall armyworm, Spodoptera frugiperda (J. E. Smith, 1797) (Lepidoptera: Noctuidae), a native to the Americas and recently reported in Africa, Germany, the Netherlands and India, is a significant pest of many crop species. Although a widespread and important pest, information on its biology and development are incomplete and require detailed study. In this study, the biotic potential and reproductive parameters of $S$. frugiperda were evaluated under controlled conditions $\left(25 \pm 1{ }^{\circ} \mathrm{C}, 70 \pm 10 \% \mathrm{RH}\right.$ and 14 hour photophase). The longevity, pre-, postand oviposition periods, fecundity, and fertility of 30 pairs were evaluated. The longevity of females (10.87 days) was not significantly different from that of males (10.90 days). The mean durations of the pre-, post- and oviposition periods were $2.63,0.53$ and 7.70 days, respectively. The mean fecundity was $2,370.66$ eggs per female and mean fertility was 2,309.03 larvae per female. On average, a female copulated 1.6 times. The biotic potential of $S$. frugiperda was estimated at $2.086 \times 10^{29}$ individuals/female/year. The net reproductive rate (Ro) was 1,079.73 times per generation and the mean generation time (T) was 32.00 days. The intrinsic rate of increase $(\mathrm{rm})$ was 0.22 , with a finite rate of increase $(\lambda)$ of 1.24 per day. This study evaluates and describes the biological parameters of $S$. frugiperda with special emphasis on its biotic potential and reproductive parameters. This information will improve the development of integrated pest management (IPM) and insect resistance management (IRM) for this species.
\end{abstract}

Key words: fall armyworm, development, fecundity, reproduction, spermatophore

\section{Introduction}

The fall armyworm, Spodoptera frugiperda (J. E. Smith, 1797) (Lepidoptera: Noctuidae), is native to the Americas (e.g., Silva et al., 1968; Fergusson et al., 1991; Pogue, 2002; Murúa et al., 2008), and has recently been reported in Africa (Goergen et al., 2016), Germany, the Netherlands and India (Invasive Species Compendium Datasheets [CABI], 2017; Kalleshwaraswamy et al., 2018). Larvae have the potential to consume 353 different plant species belonging to 76 botanical families (Montezano et al., 2016), including crops, weeds, ornamental plants and seedlings in nurseries (e.g., Luginbill, 1928; Silva et al., 1968; Labrador, 1967; Coto et al., 1995; Pogue, 2002; Pastrana, 2004; Casmuz et al., 2010; Montezano et al., 2016), but greatest damage occurs in grasses such as maize and sorghum, and in other monoculture crops such as cotton and soybean (Pitre \& Hogg, 1983; Bueno et al., 2011; Hardke et al., 2015). 
Due to $S$. frugiperda's economic importance, its polyphagous nature, voracity of feeding, and periodic outbreaks have been widely reported in the literature for many years (Luginbill, 1928; Hynes, 1942; Labrador, 1967; Silva et al., 1968; Ferguson et al., 1991; Coto et al., 1995; Pogue, 2002; Pastrana, 2004; Casmuz et al., 2010). Spodoptera frugiperda has highly plastic traits that include polyphagy, the use of different vegetal tissues (e.g., flowers, leaves, and fruits), high environmental adaptability, wide geographic range, and vitality, providing high survival.

Although S. frugiperda is such a widespread pest of many crop species, detailed biological parameters of its adult stage and biotic potential is lacking. As demonstrated for other species of Spodoptera, factors related to the reproductive behavior, such as the number of matings, is an important factor in adult longevity and fecundity (Kehat \& Gordon, 1975; Etman \& Hooper, 1979; Ellis \& Steele, 1982; Rogers \& Marti Jr., 1997; Montezano et al., 2013b, 2014b, 2015b; Specht \& Roque-Specht, 2016), and such information can influence population parameters and help to understand pest development. This information is necessary for the improvement of $S$. frugiperda integrated pest management (IPM) and insect resistance management (IRM).

The present study describes the developmental biological parameters of $S$. frugiperda under controlled conditions, with special emphasis on its fertility, biotic potential and life table parameters, and complements a previous study describing the biology of immature S. frugiperda (Montezano et al., 2019). Results presented in this study are compared to other representatives of this genus: $S$. albula, S. cosmioides, S. dolichos and $S$. eridania, which were previously published and reared under the same conditions (Montezano et al., 2013a, 2013b, 2014a, 2014b, 2015a, 2015b, 2017; Specht \& Roque-Specht, 2016).

\section{Material and Methods}

Experiments were conducted at the Entomology Laboratory of Embrapa Cerrados, Planaltina, Federal District, Brazil. A S. frugiperda colony was initiated with 54 caterpillars collected from conventional corn ears at Embrapa Cerrados experimental station ( $15^{\circ} 36^{\prime} 34.9^{\prime \prime} \mathrm{S}, 47^{\circ} 44^{\prime} 36.7^{\prime \prime} \mathrm{W}, 1170 \mathrm{~m}$ a.s.l.). The larvae were reared on artificial larval diet (also used for rearing S. eridania, S. albula, S. dolichos and S. cosmioides) (Montezano et al., 2013a, 2014b, 2015a; Specht \& Roque-Specht, 2016) adapted from Greene et al. (1976). The entire recipe and preparation are published in Montezano et al. (2013a). Only the first-generation specimens were used for the current study. To avoid the effects of adult age on the capacity to copulate, male/female pairs were formed with adults that emerged on the same day (e.g., Ellis \& Steele, 1982; Rogers \& Marti Jr., 1994). Molecular analysis indicated that the $S$. frugiperda population studied belongs to the corn-strain (Montezano et al., 2019).

To evaluate the effect of pupal weight on reproductive characteristics (Tisdale \& Sappington, 2001; Specht et al., 2016), pupae were weighed on the second day after metamorphosis, and fecundity was correlated with pupal weight. Adults were kept in pairs $(\mathrm{n}=30)$ within cylindrical plastic containers $(10 \mathrm{~cm}$ in diameter and $15 \mathrm{~cm}$ high) with long filter paper strips attached to stimulate oviposition. The tops of the containers were closed with plastic film and the bottoms were closed with Petri dishes $(10.5 \mathrm{~cm}$ diameter $)$ lined with filter paper. The adult diet was composed of honey $(10 \mathrm{~g})$, sorbic acid $(1 \mathrm{~g})$, methylparaben $(1 \mathrm{~g})$, sucrose $(60 \mathrm{~g})$, and distilled water $(1000 \mathrm{ml})$ (Hoffmann-Campo et al., 1985). All components were dissolved in distilled water and the resulting solution was kept under refrigeration $\left(7^{\circ} \mathrm{C}\right)$. Pilsen beer (Cerveceria Costa Rica, Heredia, Costa Rica) was added to the solution daily at a proportion of 1:4 beer to diet, and made available to the insects in a $5 \mathrm{~cm}$ Petri dish lined with cotton wool. Autoclaved water was provided in another $5 \mathrm{~cm}$ cotton wool lined Petri dish. Containers were examined daily to record adult survival and to remove and count the number of eggs. Dead females were dissected to determine the number of spermatophores received during copulation. Fecundity (number of eggs per female), fertility (number of hatched larvae per female), longevity, and the duration of the pre-oviposition, post-oviposition and oviposition periods were determined.

To estimate fertility, the viability of 27 egg masses (including the first and the last egg mass, totaling 8,508 evaluated eggs) taken from eight mated pairs was evaluated. Each egg cluster was placed in a Petri dish lined with filter paper moistened with distilled water until larval eclosion. All the evaluated egg masses were from females that had at least one spermatophore in the bursa copulatrix. The determination of the presence of spermatophores was done after death to verify fertilization of females during the experiment. All experiments were performed in a rearing room $\left(25 \pm 1{ }^{\circ} \mathrm{C}, 70 \pm 10 \% \mathrm{RH}\right.$ and a 14 hour photophase) with evaluations performed daily at 2:00 PM.

All biological parameters were analyzed using descriptive statistics. The fecundity, longevity of both sexes, and the duration of pre- and post-oviposition periods were correlated with the number of copulations for each couple: unmated females ( $\mathrm{n}=3$ pairs), mated once $(\mathrm{n}=11$ pairs $)$, mated twice $(\mathrm{n}=11$ pairs $)$, and mated three times $(\mathrm{n}=$ 5 pairs). Shapiro-Wilk was used to confirm normality of data, and Levene's test to assess the equality of 
variances. Analysis of variance (ANOVA) was used to verify the significance of the treatments and Tukey's post-hoc test was used for the comparison of the means at a $5 \%$ probability level $(\alpha=0.05)$.

Pearson's linear correlation method was used to verify possible association between fecundity and pupal weight followed by simple linear regression to assess how fecundity was influenced by pupal weight. To verify the significance of the coefficients of the model (linear coefficient and linear coefficient), a t-test was used. To verify the quality of the adjusted model, the coefficient of determination $\left(\mathrm{R}^{2}\right)$ was used. All statistical procedures were performed in SPSS version 19.

Biotic Potential (BP) was calculated using the equation described in Silveira-Neto et al. (1976):

$$
B P=(s r \times d)^{n}-e r
$$

where, (sr) sex ratio is the number of females divided by the number of females plus number of males; (d) viable individuals per female consisting of the number of eggs per female (or fecundity) multiplied by total survival; (n) number of generations per year or 365 days divided by the total lifespan; and (er) environmental resistance, in this case considered as null.

The biotic potential and fertility life table were developed using data from the immature stages of $S$. frugiperda reared in accordance with the methodology of Montezano et al. (2015a). The data is graphically presented by plotting the probability of survival values at the midpoint of each time interval, (survival rate $-l_{x}$ ), and the total number of eggs per female per week which became females (specific fertility $-\mathrm{m}_{\mathrm{x}}$ ).

Using the life table, the values of S. frugiperda reproductive parameters were calculated. The net reproductive rate $\left(\mathrm{R}_{0}\right)$, given by the ratio between the number of females in two successive generations; the mean generation time (T), which is the mean number of days from the birth of the parents to the birth of offspring; the daily intrinsic rate of increase $\left(\mathrm{r}_{\mathrm{m}}\right)$, and the daily finite rate of increase $(\lambda)$ followed the formulas in Silveira-Neto et al. (1976).

\section{Results}

The mean longevity, mean length of pre-, post- and oviposition periods, and mean fecundity of 30 male-female pairs of moths are presented in Table 1 . The mean fertility (calculated using $97.40 \%$ egg viability from Montezano et al. (2019) was 2,309.030 larvae per S. frugiperda female. The average number of copulations per female was 1.60 , while three (10\%) did not copulate, eleven copulated only once (36.67\%), eleven copulated twice $(36.67 \%)$ and five copulated three times $(16.67 \%)$.

Unmated females had a lower mean daily number of unfertilized eggs and the length of the pre- and oviposition periods were significant later and longer when compared with females that mated (Figure 1). The pre- and oviposition periods were significantly higher for females that did not mate $(\mathrm{F}=33.427, \mathrm{P}<0.001$, and $\mathrm{F}=6.539$, $\mathrm{P}=0.002$, respectively; Figures 2 and 3). Such differences were responsible for the increased longevity of the unmated females and males with respect to those that mated $(\mathrm{F}=7.167, \mathrm{P}<0.001$; Figure 4). Fecundity was positively affected by the number of matings $(\mathrm{F}=4.809, \mathrm{P}=0.009)$, as females which were not mated oviposited less than half of those which were fertilized, with significant differences between unmated females, and those mating once, twice, or three times (Figure 5).

Table 1. Means, standard deviation (SD) and range of longevity, pre-, post- and oviposition periods and fecundity of 30 Spodoptera frugiperda pairs under controlled conditions $\left(25 \pm 1{ }^{\circ} \mathrm{C}, 70 \pm 10 \% \mathrm{RH}\right.$ and a 14 hour photophase)

\begin{tabular}{lllll}
\hline Sex & Biological parameter & Mean & SD & Range \\
\hline Both & Longevity (days) & 10.883 & 2.906 & $6-19$ \\
\hline Female & Longevity (days) & 10.867 & 3.627 & $6-19$ \\
& Pre-oviposition (days) & 2.633 & 1.033 & $2-6$ \\
& Post-oviposition (days) & 0.533 & 0.681 & $0-2$ \\
& Oviposition (days) & 7.700 & 2.070 & $4-12$ \\
& Fecundity (eggs) & $2,370.667$ & 964.593 & $346-4,789$ \\
Male & Longevity (days) & 10.900 & 2.928 & $6-18$
\end{tabular}

Note. Comparison of male and female mean longevity using a Student $t$-test, considering different variances, at $5 \%$ level of significance ( $\mathrm{ns}, \mathrm{p}=0.163$ ). 


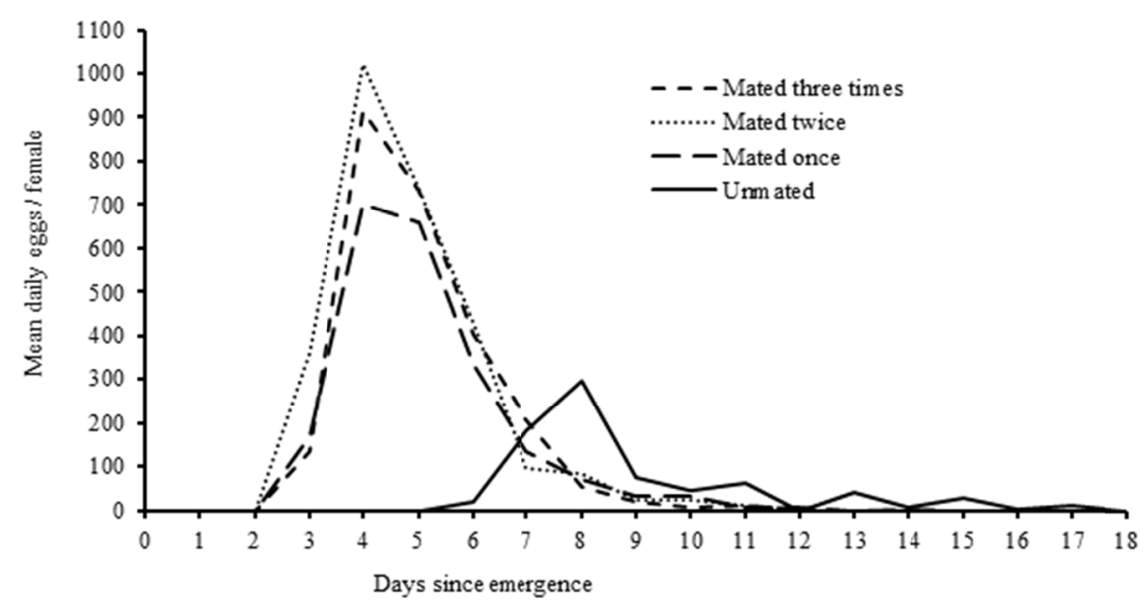

Figure 1. Daily mean number of eggs of Spodoptera frugiperda, which unmated $(\mathrm{n}=3)$, mated once $(\mathrm{n}=11)$, twice $(n=11)$ or three times $(n=5)$. One couple per cage at $25 \pm 1{ }^{\circ} \mathrm{C}, 70 \pm 10 \%$ RH and a 14 hour photophase

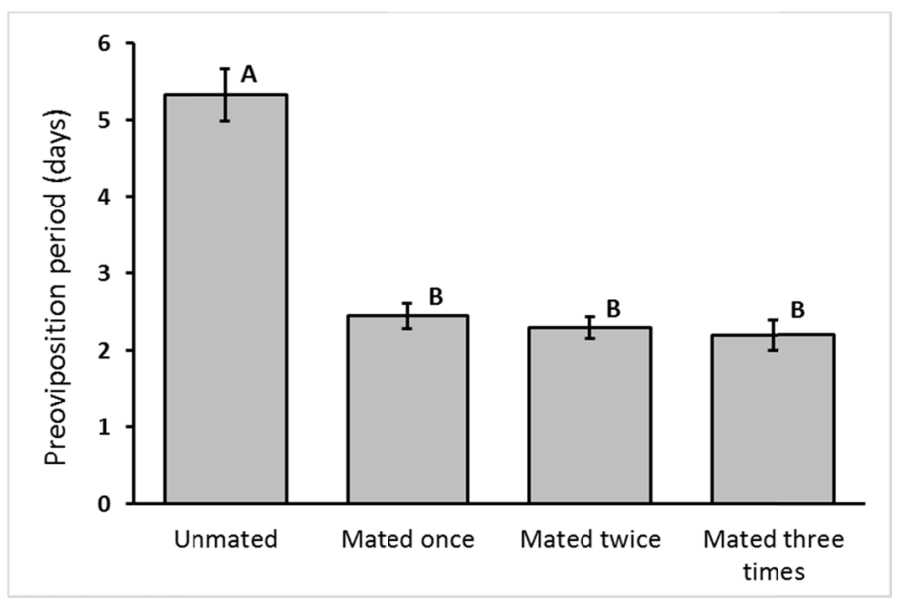

Figure 2. Pre-oviposition period of Spodoptera frugiperda which unmated $(\mathrm{n}=3)$, mated once $(\mathrm{n}=11)$, twice ( $\mathrm{n}$ $=11)$ or three times $(n=5)$. One couple per cage at $25 \pm 1{ }^{\circ} \mathrm{C}, 70 \pm 10 \% \mathrm{RH}$ and a 14 hour photophase. Means and standard deviations followed by the same letter are not statistically different from each other by Tukey test, at $5 \%$ probability

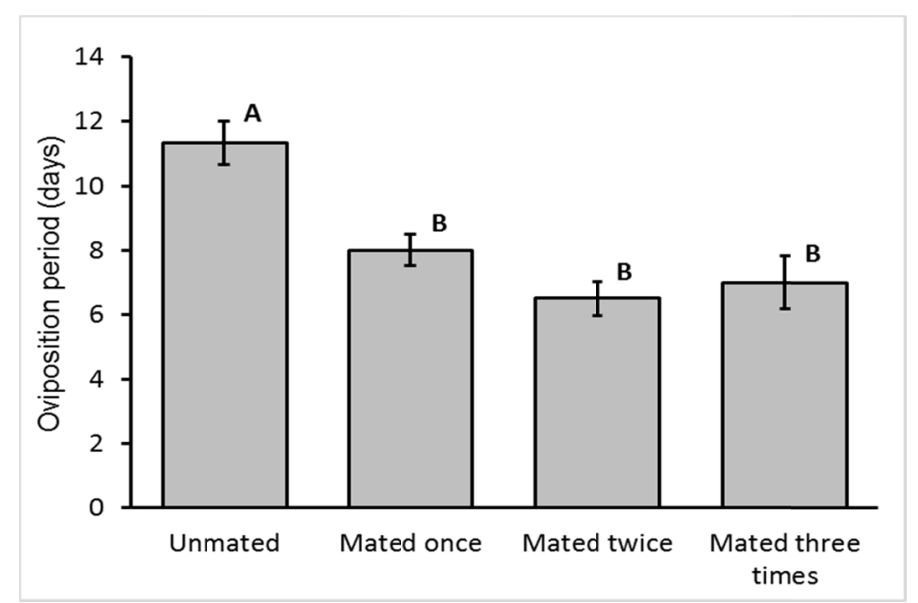

Figure 3. Oviposition period of Spodoptera frugiperda which unmated $(n=3)$, mated once $(n=11)$, twice $(n=$ 11 ) or three times $(n=5)$. One couple per cage at $25 \pm 1{ }^{\circ} \mathrm{C}, 70 \pm 10 \% \mathrm{RH}$ and a 14 hour photophase. Means and standard deviations followed by the same letter are not statistically different from each other by Tukey test, at $5 \%$ probability 


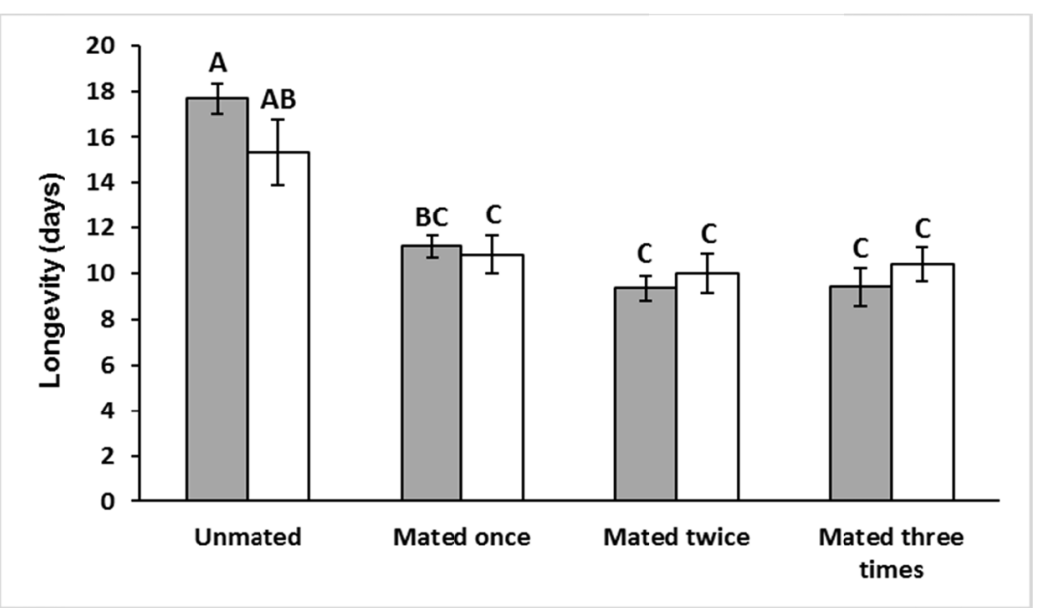

Figure 4. Longevity of Spodoptera frugiperda females (grey bars) and males (empty bars), unmated $(\mathrm{n}=3)$, mated once $(n=11)$, twice $(n=11)$ or three times $(n=5)$. One couple per cage at $25 \pm 1{ }^{\circ} \mathrm{C}, 70 \pm 10 \% \mathrm{RH}$ and a 14 hour photophase. Means and standard deviations followed by the same letter are not statistically different from each other by Tukey test, at $5 \%$ probability

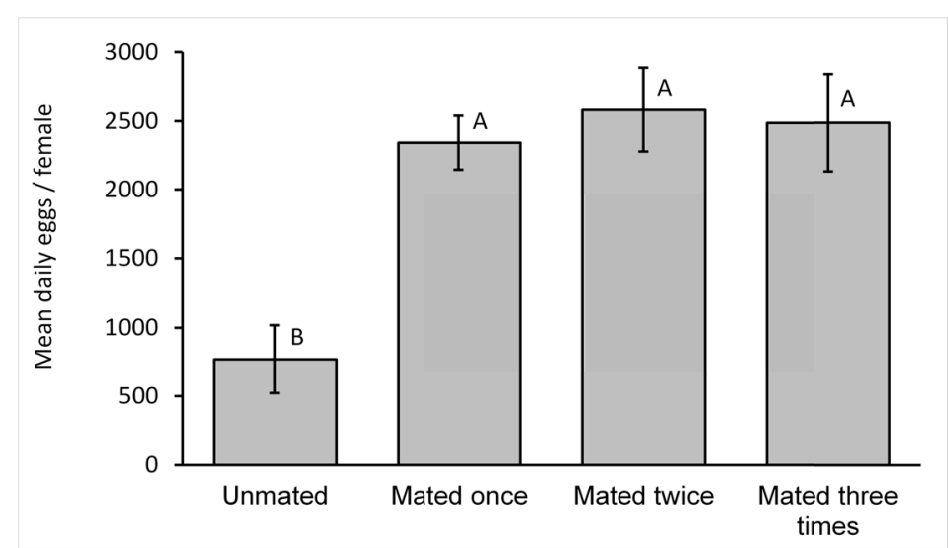

Figure 5. Mean fecundity of Spodoptera frugiperda that unmated $(n=3)$, mated once $(n=11)$, twice $(n=11)$ or three times $(\mathrm{n}=5)$. One couple per cage at $25 \pm 1{ }^{\circ} \mathrm{C}, 70 \pm 10 \%$ RH and a 14 hour photophase. Means and standard deviations followed by the same letter are not statistically different from each other by Tukey test, at $5 \%$ probability

The maximum rate of population growth occurred between 30 and 31 days after hatching, during the 4th and 5th week of life, represented by the intersection of the specific survival and fertility lines (Figure 6). This rate is shifted towards the beginning of the adult phase, due to both the high fertility of adults soon after emergence and the low mortality of hatching immature. 


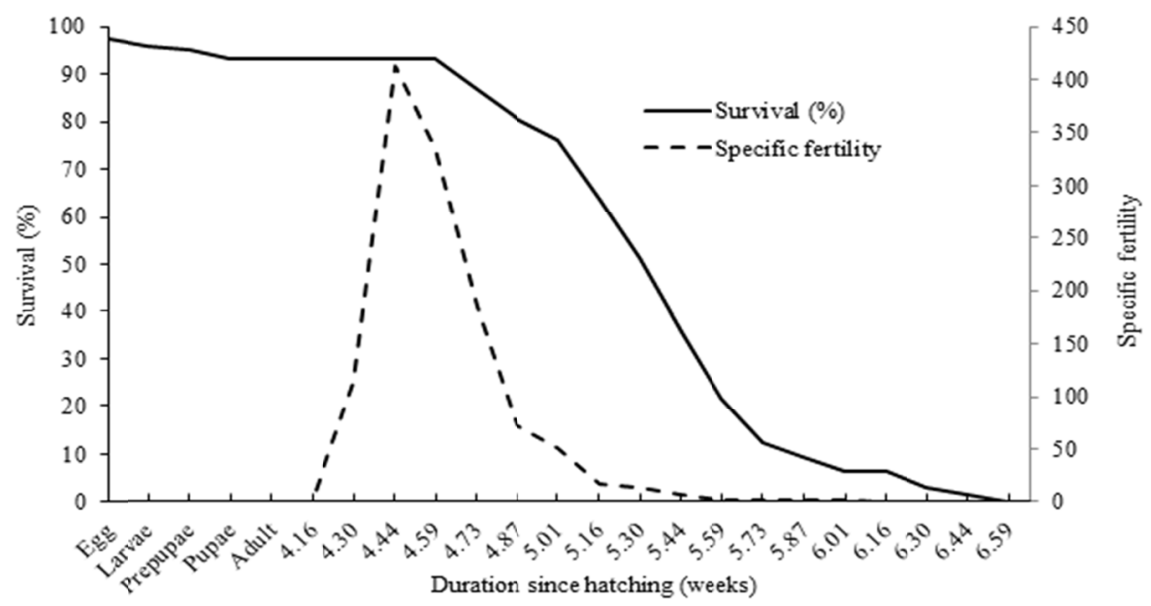

Figure 6. Relation between fertility $\left(\mathrm{m}_{\mathrm{x}}\right)$ and survival rate $\left(\mathrm{l}_{\mathrm{x}}\right)$ of Spodoptera frugiperda reared on an artificial diet at $25 \pm 1{ }^{\circ} \mathrm{C}, 70 \pm 10 \% \mathrm{RH}$ and a 14 hour photophase

The net reproductive rate $\left(\mathrm{R}_{0}\right)$ was $1,079.730$ females per generation, the mean generation time $(\mathrm{T})$ was 31.999 days, the daily intrinsic rate of increase $\left(r_{m}\right)$ was 0.218 , and the daily finite rate of increase $(\lambda)$ was 1.244.

Pearson's linear correlation indicates a high positive association $(r=0.895)$ between fecundity and pupal weight (Figure 7). The simple linear regression analysis shows that the increase in fecundity is directly related to the increase in pupal weight at an $80.13 \%\left(\mathrm{R}^{2}\right)$ level, according to the equation $\mathrm{y}=-978.959+15.236 \mathrm{x}$, where $\mathrm{y}=$ fecundity and $\mathrm{x}=$ pupal weight. Both the angular and the linear coefficient were statistically significant at $5 \%$ and $0.1 \%$ levels, respectively.

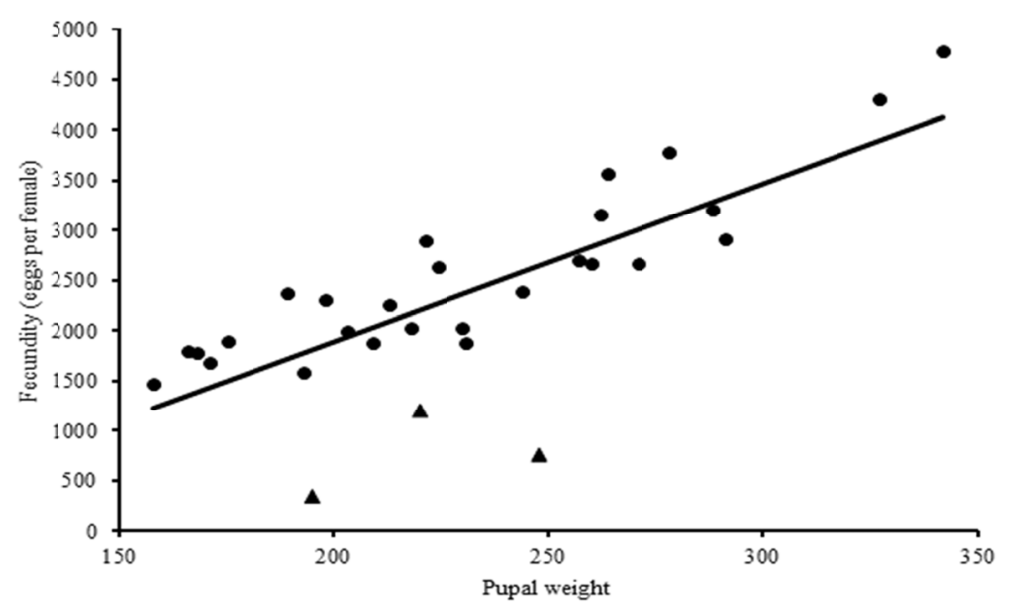

Figure 7. Relation between pupal weight (mg) and fecundity of mated Spodoptera frugiperda females (dark circles) at $25 \pm 1{ }^{\circ} \mathrm{C}, 70 \pm 10 \% \mathrm{RH}$ and a 14 hour photophase, with larvae reared on artificial diet. The fecundity of three unmated females (dark triangles) is also plotted but they were not being considering in the analysis

The biotic potential was calculated from the equation $\mathrm{BP}=(\mathrm{sr} \times \mathrm{d})^{\mathrm{n}}-$ er. So $\mathrm{BP}=(0.509 \times 2,208.987)^{11.407}-0=$ $2.086 \times 10^{29}$ individuals per female per year. It was assumed that 146 female and 141 male immature reached the pupal stage at a 0.51 ratio (Montezano et al., 2019). On average, each female oviposited 2,370.66 eggs and the overall survival was 93\%, (Montezano et al., 2019) resulting in 2,208.98 viable individuals per female, the average duration of the life cycle (37.97 days), corresponds to 9.611 generations per year (n), considering the environmental resistance as null.

\section{Discussion}

Adult S. frugiperda longevity plus immature duration (Montezano et al., 2019) is 37.97 days, which is shorter than observed for all other species reared under the same conditions: S. albula (43.99 days), S. eridania (40.96 days), S. cosmioides (54.41 days) and S. dolichos (63.10 days) (Montezano et al., 2013a, 2013b, 2014a, 2014b, 
2015a, 2015b, 2019; Specht \& Roque-Specht, 2016). Therefore, the results indicate that S. frugiperda presents the fastest development among all Spodoptera species studied to date (Pogue, 2002).

As demonstrated for other species of Spodoptera, the number of matings is an important factor in adult longevity (Kehat \& Gordon, 1975; Etman \& Hooper, 1979; Ellis \& Steele, 1982; Rogers \& Marti Jr., 1997; Montezano et al., 2013b, 2014b, 2015b; Specht \& Roque-Specht, 2016), especially considering the prolonged pre-oviposition and oviposition periods of the females that are not mated. Compared to the longevity of the immature stages (27.10 days) (Montezano et al., 2019), the average longevity of S. frugiperda adults makes up $28.64 \%$ of their entire life cycle. These results are similar to those reported for $S$. albula (28.32\% adult stage) (Montezano et al., 2013a, 2014a), but greater than those reported for S. eridania (24.5\%) (Montezano et al., 2013b, 2014b), S. dolichos $(20.50 \%)$ (Montezano et al., 2015ab, 2016) and S. cosmioides (25.30\%) (Specht \& Roque-Specht, 2016) reared under the same conditions. The greater adult longevity of $S$. frugiperda is important to its wide distribution within the Americas, extending between the parallels $30^{\circ}$ North and South (e.g., Pogue, 2002; Pastrana, 2004; Nagoshi et al., 2017), similar to other species of Spodoptera which also have a great ability for dispersal and migration (e.g., Johnson, 1987; Ferguson et al., 1991; Nagoshi et al., 2012, 2017).

The maximum number of matings observed in this study (three matings with one moth pair per container) was less than that reported in other studies: five matings when moths were maintained under similar conditions (Garcia \& Clavijo, 1989), eight when 25 pairs were maintained per container (Milano et al., 2008), and eleven with one female and two males per container (Simmons \& Marti Jr., 1992). However, considering the mean number of matings with just one couple per container in this study (1.6), this is similar to the data reported for the same species by Garcia and Clavijo (1989), with 1.7 matings, and Murúa et al. (2008), where variability was observed between different $S$. frugiperda populations in Argentina (0.78 to 2.32 matings). Regarding the absence of mating for some S. frugiperda pairs, studies with single pairs (Garcia \& Clavijo, 1989; Murúa et al., 2008), multiple pairs (Milano et al., 2008), and one female and two males (Simmons \& Marti Jr., 1992) have also reported unmated females. When compared with other Spodoptera species under similar conditions, the number of matings per pair was similar to what was described for S. albula, S. eridania, S. cosmioides and S. dolichos (Montezano et al., 2013b, 2014a, 2016; Specht \& Roque-Specht, 2016). The strong positive correlation between the number of matings and fecundity observed for $S$. frugiperda is similar to that for one female with two males per cage (Simmons \& Marti Jr., 1992) and multiple pairs per cage (Burton \& Perkins, 1972; Milano et al., 2008). This suggests that in nature, where the possibility of encounters between moths is high, the number of matings will be high, thus increasing fecundity. Simmons and Marti Jr. (1992) state in a personal communication from Silvian and Remillet that most field-mated (French Guiana) females had 2-4 spermatophores, and one contained nine spermatophores.

The significant increase in the duration of the pre-oviposition and oviposition periods of the unmated females indicates that $S$. frugiperda presents an increase of the pre-oviposition and oviposition period as a function of the absence of mating, which is also reflected as prolonged longevity (Rogers \& Marti Jr., 1994). This result was also reported in S. cosmioides (Specht \& Roque-Specht, 2016), S. dolichos (Montezano et al., 2016), S. eridania (Montezano et al., 2013b), S. exigua (Rogers \& Marti Jr., 1997), S. littoralis (Kehat \& Gordon, 1975; Ellis \& Steele, 1982) and S. litura (Etman \& Hooper, 1979).

The significant reduction in the oviposition period for moths that had mated one or more times is related to the interaction between egg production and metabolism (Hou \& Sheng, 1999). It is suggested that multiple matings stimulate egg production and accelerate the use of energy and resources, reducing the resources available for somatic maintenance. However, the reduction of the oviposition period associated with a greater number of matings, as described by Hou and Sheng (1999), is likely related to the increase of the reproductive activity in females which copulated more.

The presence of a pre-oviposition period indicates that $S$. frugiperda, as with $S$. albula and $S$. eridania (Montezano et al., 2013b, 2014b) under the same conditions, need at least two days after emergence to begin oviposition. However, the sexual maturity of S. frugiperda occurs soon after emergence (Simmons \& Marti Jr., 1992; Rogers \& Marti Jr., 1994; Busato et al., 2006), as in other Spodoptera species (e.g., Etman \& Hooper, 1979; Habib et al., 1983; Tisdale \& Sappington, 2001). Our results confirm that the initial mating of $S$. frugiperda occurs between the first and second day after emergence. The onset of oviposition, at least in the first days after emergence, is conditioned on the occurrence of the first mating, as observed for S. albula (Montezano et al., 2014a), S. cosmioides (Specht \& Roque-Specht, 2016), S. dolichos (Montezano et al., 2016), S. eridania (Montezano et al., 2013b) and S. exigua (Roger \& Marti Jr., 1997). However, as already reported by Martin et al. (1989), and Simmons and Martin Jr. (1992) and reported in Figure 5, the importance of multiple mating may be marginal for S. frugiperda egg production because it is not a prerequisite for continued egg production. 
The fecundity of $S$. frugiperda was highly variable, and positively correlated with pupal weight. This result was similar to the reported fecundity of rice biotype larvae fed on Greene et al. (1979) artificial diet (2,263 eggs/female; Busato et al., 2006) or larvae fed on corn leaves (2,348-2,356 eggs/female; Hynes, 1942; Garcia \& Clavijo, 1989). However, the majority of studies report averages between 1,000-2,000 eggs/female (e.g., Campos, 1970; Leuck \& Perkins, 1972; Vázquez \& García, 1975; Combs \& Valerio, 1980; Pencoe \& Martin, 1982; Veloso et al., 1983; Garcia \& Clavijo, 1989; Lynch et al., 1989; Rizzo \& La Rossa, 1992; Botton et al., 1998; Santos et al., 2004; Busato et al., 2006; Lopes et al., 2008; Barros et al., 2010; Campos et al., 2011; Nabity et al., 2011; Silva \& Parra, 2013). The maximum fecundity rate presented in this study $(4,789$ eggs/female) was similar to that of Hynes (1942): 4,963 eggs/female. Busato et al. (2006) reports 3,335 eggs for one female (corn biotype) and Milano et al. (2008) reports values higher than 3,000 eggs per females kept under 20, 25 and $30^{\circ} \mathrm{C}$. Other studies reporting the maximum number of eggs per female report an average of 2,500 eggs/female (Leiderman \& Sauer, 1953; Campos, 1970; Leuck \& Perkins, 1972; Busato et al., 2006). Fecundity of S. frugiperda was much higher than observed for similar sized $S$. albula and $S$. eridania reared under the same conditions (Montezano et al., 2013b, 2014a). However, it was less than that of the larger S. dolichos (Montezano et al., 2016) and $S$. cosmioides (Bavaresco et al., 2004; Specht \& Roque-Specht, 2016). The high correlation between pupal weight and fecundity demonstrates the importance of diet for larval development and resultant pupal weight (e.g., Bavaresco et al., 2004; Busato et al., 2006; Specht et al., 2016).

Biotic potential $\left(2.086 \times 10^{29}\right.$ individuals/female/year) of $S$. frugiperda was higher than observed for $S$. albula, $S$. cosmioides, S. dolichos and S. eridania under the same conditions (Montezano et al., 2013b, 2014a; Montezano et al., 2016; Specht \& Roque-Specht, 2016), especially influenced by the short life cycle duration, reflected by a mean generation time $(T)$ of 32.0 days. The net reproductive rate $\left(\mathrm{R}_{0}=1,079.730\right.$ females per generation), resulting in a relatively high daily intrinsic rate of increase $\left(\mathrm{r}_{\mathrm{m}}=0.218\right)$ and daily finite rate of increase $(\lambda=$ 1.244), was also higher than those observed for $S$. albula, S. cosmioides, $S$. dolichos and $S$. eridania under the same conditions (Montezano et al., 2013b, 2014a; Montezano et al., 2016; Specht \& Roque-Specht, 2016). Previous studies (e.g., Busato et al., 2006; Montezano et al., 2015b; Specht \& Roque-Specht, 2016) indicate that larger Spodoptera species, such as S. cosmioides and S. dolichos, have longer developmental times compensated with higher fecundity when compared to smaller species such as $S$. albula and $S$. eridania (Montezano et al., 2013a, 2014b). However, S. frugiperda has a higher biotic potential due to the combination of shorter development time and higher fecundity.

The maximum population increase rate for S. frugiperda occurs during the beginning of the adult stage, driven by the higher fertility and low mortality of the immature individuals shortly after hatching. These observations are consistent with other S. frugiperda studies (Campos, 1970; Pencoe \& Martin, 1982; García \& Clavijo, 1989; Santos et al., 2004) and those with other Spodoptera species where the highest fecundity values are observed during the first days after emergence (Kehat \& Gordon, 1975; Sadek, 2001; Bavaresco et al., 2004; Murúa \& Virla, 2004; Busato et al., 2006; Montezano et al., 2013b, 2014a, 2015b; Specht \& Roque-Specht, 2016).

Results presented in this study demonstrate that $S$. frugiperda females that did not mate delayed the beginning of the oviposition period. Results also reported by Kehat and Gordon (1975), and Ellis and Steele (1982) which showed that in Spodoptera littoralis the delay of the first mating negatively influences population parameters. These results illustrate the possible importance of studies on the identification and use of $S$. frugiperda pheromones (e.g., Sekul \& Sparks, 1967; Jones \& Sparks, 1979; Mitchell et al., 1985; Tumlinson et al., 1986; Meagher \& Mitchell, 1998; Andrade et al., 2000; Batista-Pereira et al., 2006) to delay or disrupt mating (Carde $\&$ Minks, 1995) as a strategy for the integrated management of this species.

When comparing the results obtained in this study to others conducted under the same conditions with $S$. albula, S. cosmioides, S. dolichos and S. eridania (Montezano et al., 2013a, 2013b, 2014a, 2014b, 2015a, 2015b, 2019; Specht \& Roque-Specht, 2016), S. frugiperda presents higher biotic potential from the combination of faster development, higher survival and high fecundity. Such factors should be considered in all areas of occurrence of this pest, which now includes the African, European and Asian continents (Goergen et al., 2016; CABI, 2017), and especially in areas where major host plants of $S$. frugiperda are cultivated. Results presented in this study represent optimum developmental conditions for the pest, including temperature, photoperiod, suitable diet, and absence of natural enemies. However, it is possible that additional factors that favor $S$. frugiperda and improve the chances of mating and reproductive success exist in nature, which are not possible to reproduce in the laboratory, such as daily variations of temperature and luminosity, pheromone release, and availability of host plants. Therefore, all observations made under laboratory conditions must be compared with detailed studies examining population temporal effects for field collected specimens when considering genetics (e.g., biotype 
identification), individual size (e.g., wingspan correlated with suitability of host plant and/or starvation) and number of mating events.

\section{Acknowledgements}

The authors thank the National Council for Scientific and Technological Development (CNPq) for the productivity grants (proc. $n^{\circ} .306601 / 2016-8,305649 / 2013-2$ and proc. $n^{\circ} .308947 / 2014-2$ ) in research offered to the first author and second author, respectively, and for the research funding (proc $\mathrm{n}^{\circ}$. 403376/2013-0) and for Brazilian Agricultural Research Corporation-Embrapa for the research funding (MP2 02.13.14.006.00.00) To Instituto Chico Mendes (ICMBio)-Ministério do Meio Ambiente do Brasil-Authorization for scientific activities SISBIO 38547/(1-6).

\section{References}

Andrade, R., Rodriguez, C., \& Oehlschlager, A. C. (2000). Optimization of a pheromone lure for Spodoptera frugiperda (Smith) in Central America. Journal of the Brazilian Chemical Society, 11(6), 609-613. https://doi.org/10.1590/S0103-50532000000600009

Barros, E. M., Torres, J. B., \& Bueno, A. F. (2010). Oviposição, desenvolvimento e reprodução de Spodoptera frugiperda (J. E. Smith) (Lepidoptera: Noctuidae) em diferentes hospedeiros de importância econômica. Neotropical Entomology, 39(6), 996-1001. https://doi.org/10.1590/S1519-566X2010000600023

Bavaresco, A., Garcia, M. S., Grützmacher, A. D., Ringenberg, R., \& Foresti, J. (2004). Adequação de uma dieta artificial para a criação de Spodoptera cosmioides (Walk.) (Lepidoptera: Noctuidae) em laboratório. Neotropical Entomology, 33(2), 155-161. https://doi.org/10.1590/S1519-566X2004000200005

Batista-Pereira, L. G., Stein, K., De Paula, A. F., Moreira, J. A., Cruz, I., Figueiredo, M. L. C., ... Corrêa, A. G. (2006). Isolation, identification, synthesis, and field evaluation of the sex pheromone of the Brazilian population of Spodoptera frugiperda. Journal of Chemical Ecology, 32(5), 1085-1099. https://doi.org/10.1007/ s10886-006-9048-5

Botton, M., Carbonari, J. J., Garcia, M. S., \& Martins, J. F. S. (1998). Preferência alimentar e biologia de Spodoptera frugiperda (J. E. Smith) (Lepidoptera: Noctuidae) em arroz e capim-arroz. Anais da Sociedade Entomológica do Brasil, 27(2), 207-212. https://doi.org/10.1590/S0301-80591998000200006

Bueno, R. C. O. F., Bueno, A. F., Moscardi, F., Parra, J. R., \& Hoffmann-Campo, C. B. (2011). Lepidopteran larvae consumption of soybean foliage: Basis for developing multiple-species economic thresholds for pest management decisions. Pest Management Science, 67(2), 170-174. https://doi.org/10.1002/ps.2047

Burton, R. L., \& Perkins, W. D. (1972). WSB, a new laboratory diet for the corn earworm and the fall armyworm. Journal of Economic Entomology, 65(2), 385-386. https://doi.org/10.1093/jee/65.2.385

Busato, G. R., Garcia, M. S., Loeck, A. E., Zart, M., Nunes, A. M., Bernardi, O., \& Andersson, F. S. (2006). Adequação de uma dieta artificial para biótipos "milho" e "arroz" de Spodoptera frugiperda (Lepidoptera: Noctuidae). Bragantia, 65(2), 317-323. https://doi.org/10.1590/S0006-87052006000200014

CABI. (2017). Invasive Species Compendium Datasheets-Spodoptera frugiperda (fall armyworm). Retrieved from http://www.cabi.org/isc/datasheet/29810

Campos, F. J. (1970). Ciclo biológico y potencial biótico de Spodoptera frugiperda (J. E. Smith) en dietas natural y artificial. Investigaciones Agropecuárias del Peru, 1, 31-36.

Campos, A. P., Boiça Jr., A. L., Jesus, F. G., \& Godoy, I. J. (2011). Avaliação de cultivares de amendoim para resistência a Spodoptera frugiperda. Bragantia, 70, 349-355. https://doi.org/10.1590/S0006-87052011000 200014

Casmuz, A., Juárez, M. L., Socías, M. G., Murúa, M. G., Prieto, S., Medina, S., ... Gastaminza, G. (2010). Revisión de los hospederos del gusano cogollero del maíz, Spodoptera frugiperda (Lepidoptera: Noctuidae). Revista de la Sociedad Entomológica, 69(3-4), 209-231.

Cardé, R. T., \& Minks, A. K. (1995). Control of moth pests by mating disruption: Successes and constraints. Annual Review of Entomology, 40(1), 559-585. https://doi.org/10.1146/annurev.en.40.010195.003015

Combs Jr., R. L., \& Valerio, J. R. (1980). Biology of the fall armyworm on four varieties of bermudagrass when held at constant temperatures. Environmental Entomology, 9(4), 393-396. https://doi.org/10.1093/ee/9.4.393

Coto, D., Saunders, J. L., Vargas, S. C. L., \& King, B. S. (1995). Plagas invertebradas de cultivos tropicales con énfasis en América Central-Un inventario. CATIE, Turrialba. 
Ellis, P. E., \& Steele, G. (1982). The effect of delayed mating on the fecundity of females of Spodoptera littoralis (Boisduval) (Lepidoptera: Noctuidae). Bulletin of Entomological Research, 72(2), 295-302. https://doi.org/ 10.1017/S0007485300010592

Etman, A. A. M., \& Hooper, G. H. S. (1979). Developmental and reproductive biology of Spodoptera litura (F.) (Lepidoptera: Noctuidae). Australian Journal of Entomology, 18(4), 363-372. https://doi.org/10.1111/ j.1440-6055.1979.tb00868.x

Ferguson, D. C., Hilburn, D. J., \& Wright, B. (1991). The Lepidoptera of Bermuda: Their food plants, biogeography, and means of dispersal. The Memoirs of the Entomological Society of Canada, 123(S158), 1-105. https://doi.org/10.4039/entm123158fv

Garcia, R. J. L., \& Clavijo, S. A. (1989). Efecto de la alimentación sobre la longevidad, fertilidad y fecundidad de Spodoptera frugiperda (Smith). Boletín Entomologico Venezuelano, 5(6), 47-53.

Goergen, G., Kumar, P. L., Sankung, S. B., Togola, A., \& Tamò, M. (2016). First report of outbreaks of the fall armyworm Spodoptera frugiperda (J. E. Smith) (Lepidoptera, Noctuidae), a new alien invasive pest in West and Central Africa. PLOS ONE, 11, e0165632. https://doi.org/10.1371/journal.pone.0165632

Greene, G. L., Lepla, N. V., \& Dickerson, W. A. (1976). Velvetbean caterpillar: A rearing procedure and artificial medium. Journal of Economic Entomology, 69(4), 487-488. https://doi.org/10.1093/jee/69.4.487

Habib, M. E. M., Paleari, M. L., \& Amaral, E. C. (1983). Effect of three larval diets on the development of the armyworm, Spodoptera latifascia Walker, 1856 (Lepidoptera: Noctuidae). Revista Brasileira de Zoologia, 1(3), 177-182. https://doi.org/10.1590/S0101-81751982000300007

Hardke, J. T., Lorenz, G. M., \& Leonard, B. R. (2015). Fall Armyworm (Lepidoptera: Noctuidae) ecology in Southeastern Cotton. Journal of Integrated Pest Management, 6(1), 1-10. https://doi.org/10.1093/jipm/ pmv009

Hoffmann-Campo, C. B., Oliveira, E. B., \& Moscardi, F. (1985). Criação massal da lagarta da soja (Anticarsia gemmatalis) (Documentos 10, p. 23). Londrina, Embrapa-SNPSo.

Hou, M. L., \& Sheng, C. F. (1999). Fecundity and longevity of Helicoverpa armigera (Lepidoptera: Noctuidae): effects of multiple mating. Journal of Economic Entomology, 92(3), 569-573. https://doi.org/10.1093/ jee/92.3.569

Hynes, H. B. N. (1942). Lepidopterous pests of maize in Trinidad. Tropical Agriculture, 29, 194-202.

Jones, R. L., \& Sparks, A. N. (1979). (Z)-9-tetradecen-ol acetate. A secondary sex pheromone of the fall armyworm, Spodoptera frugiperda (J. E. Smith). Journal of Chemical Ecology, 5(5), 721-725. https://doi.org/10.1007/BF00986556

Kalleshwaraswamy, C. M., Asokan, R., Swamy, H. M., Maruthi, M. S., Pavithra, H. B., Hegde, K., ... Goergen, G. (2018). First report of the fall armyworm, Spodoptera frugiperda (J. E. Smith) (Lepidoptera: Noctuidae), an alien invasive pest on maize in India. Pest Management in Horticultural Ecosystems, 24(1), 23-29.

Kehat, M., \& Gordon, D. (1975). Mating, longevity, fertility and fecundity of the cotton leaf- worm, Spodoptera littoralis (Boisd.) (Lepidoptera: Noctuidae). Phytoparasitica, 3(2), 87-102. https://doi.org/10.1007/ BF03158291

Labrador, J. R. (1967). Estudio de Biología y Combate del Gusano Cogollero del maíz Laphygma frugiperda (S. \&. A). Universidad del Zulia, Venezuela, Maracaibo.

Leiderman, L., \& Sauer, H. F. G. (1953). A lagarta dos milharais (Laphygma frugiperda Abbot \& Smith, 1797). O Biológico, 19, 105-113.

Leuck, D. B., \& Perkins W. D. (1972). A method of estimating fall armyworm progeny reduction when evaluating control achieved host-plant resistance. Journal of Economic Entomology, 65(2), 482-483. https://doi.org/10.1093/jee/65.2.482

Lopes, G. S., Lemos, R. N. S., Machado, K. K. G., Maciel, A. A. S., \& Ottati, A. L.T. (2008). Biologia de Spodoptera frugiperda (J. E. Smith) (Lepidoptera: Noctuidae) em folhas de mandioca (Manihot esculenta, Crantz). Revista Caatinga, 21(3), 134-140.

Luginbill, P. (1928). The Fall Armyworm. USDA Technical Bulletin. 
Lynch, R. E., Nwanze, K. F., Wiseman, B. R., \& Perkins, W. D. (1989). Fall armyworm (Lepidoptera: Noctuidae) development and fecundity when reared as larvae on different meridic diets. Journal of Agricultural Entomology, 6(2), 101-111.

Martin, J. A., Pashley, D. P., \& Mason, L. J. (1989). Sperm use patterns of individual fall armyworm (Lepidoptera: Noctuidae). Annals of the Entomological Society of America, 82(2), 177-180. https://doi.org/ 10.1093/aesa/82.2.177

Meagher, R. L. Jr., \& Mitchell, E. R. (1998). Phenylacetaldehyde enhances upwind flight of male fall armyworm (Lepidoptera: Noctuidae) to its sex pheromone. The Florida Entomologist, 81(4), 556-559. https://doi.org/ $10.2307 / 3495958$

Milano, P., Berti Filho, E., Parra, J. R. P., \& Cônsoli, F. L. (2008). Influência da temperatura na frequência de cópula de Anticarsia gemmatalis (Hübner) e Spodoptera frugiperda (J. E. Smith) (Lepidoptera: Noctuidae). Neotropical Entomology, 37(5), 528-535. https://doi.org/10.1590/S1519-566X20080005 00005

Mitchell, E. R., Tumlinson, J. H., \& McNeil, J. N. (1985). Field evaluation of commercial pheromone formulations and traps using a more effective sex pheromone blend for the fall armyworm (Lepidoptera: Noctuidae). Journal of Economic Entomology, 78(6), 1364-1369. https://doi.org/10.1093/jee/78.6.1364

Montezano, D. G., Specht, A., Sosa-Gómez, D. R., Roque-Specht, V. F., Bortolin, T. M, Fronza, E., ... Barros, N. M. (2013a). Immature stages of Spodoptera albula (Walker) (Lepidoptera: Noctuidae): Developmental parameters and host plants. Anais da Acadêmia Brasileira de Ciências, 85(1), 271-284. https://doi.org/ $10.1590 / \mathrm{S} 0001-37652013000100013$

Montezano, D. G., Specht, A., Sosa-Gómez, D. R., Roque-Specht V. F., \& Barros, N. M. (2013b). Biotic potential and reproductive parameters of Spodoptera eridania (Stoll) (Lepidoptera, Noctuidae) in the laboratory. Revista Brasileira de Entomologia, 57(3), 340-345. https://doi.org/10.1590/S0085-56262013 005000026

Montezano, D. G., Specht, A., Sosa-Gómez, D. R., Roque-Specht, V. F. Bortolin, T. M., Fronza, E., ... Barros, N. M. (2014a). Biotic potential, fertility and life table of Spodoptera albula (Walker) (Lepidoptera: Noctuidae), under controlled conditions. Anais da Academia Brasileira de Ciências, 86(2), 723-732. https://doi.org/ 10.1590/0001-3765201402812

Montezano, D. G., Specht, A., Sosa-Gómez, D. R., Roque-Specht, V. F., \& Barros, N. M. (2014b). Immature stages of the armyworm, Spodoptera eridania: Developmental parameters and host plants. Journal of Insect Science, 14(1), 1-11. https://doi.org/10.1093/jisesa/ieu100

Montezano, D. G., Sosa-Gómez, D. R., Paula-Moraes, S. V., Roque-Specht, V. F., Fronza, E. Barros, N. M., \& Specht, A. (2015a). Immature Development of Spodoptera dolichos (Fabricius) (Lepidoptera: Noctuidae). Neotropical Entomology, 45(1), 22-27. https://doi.org/10.1007/s13744-015-0333-2

Montezano, D. G., Sosa-Gómez, D. R., Paula-Moraes, S. V., Roque-Specht, V. F., Fronza, E., Barros, N. M., \& Specht, A. (2015b). Biotic potential and reproductive parameters of Spodoptera dolichos (Fabricius, 1794) (Lepidoptera: Noctuidae), in the laboratory. Revista Zoologia, 32(6), 485-491. https://doi.org/ $10.1590 / \mathrm{s} 1984-46702015000600008$

Montezano, D. G., Specht, A., Sosa-Gómez, D. R., Roque-Specht, V. F., Sousa-Silva, J. C., Paula-Moraes, S. V., ... Hunt, T. E., 2018. Host plants of Spodoptera frugiperda (Lepidoptera: Noctuidae) in the Americas. African Entomoly, 26(2), 286-301. https://doi.org/10.4001/003.026.0286

Montezano, D. G., Specht, A., Sosa-Gómez, D. R., Roque-Specht, V. F., Paula-Moraes S. V., Peterson, J. A., \& Hunt, T. E. (2019). Developmental Parameters of Spodoptera frugiperda (Lepidoptera: Noctuidae) Immature Stages Under Controlled and Standardized Conditions. Journal of Agricultural Science, 11(8). https://doi.org/10.5539/jas.v11n8p76

Murúa, M. G., \& Virla E. (2004). Population parameters of Spodoptera frugiperda (Smith) (Lep.: Noctuidae) fed on corn and two predominant grasses in Tucuman (Argentina). Acta Zoológica Mexicana, 20(1), 199-210.

Murúa, M. G., Vera, M. T., Abraham, S., Juárez, M. L., Prieto, S., Head, G. P., \& Willink, E. (2008). Fitness and mating compatibility of Spodoptera frugiperda (Smith) (Lepidoptera: Noctuidae) populations from different host plant species and regions in Argentina. Annals of the Entomological Society of America, 101(3), 639-649. https://doi.org/10.1603/0013-8746(2008)101[639:FAMCOS]2.0.CO;2 
Nabity, P. D., Zangerl, A. R., Berenbaum, M. R., \& DeLucia, E. H. (2011). Bioenergy crops Miscanthus $\times$ giganteus and Panicum virgatum reduce growth and survivorship of Spodoptera frugiperda (Lepidoptera: Noctuidae). Journal of Economic Entomology, 104(2), 459-464. https://doi.org/10.1603/EC10311

Nagoshi, R. N., Meagher, R. L., \& Hay-Roe, M. (2012). Inferring the annual migration patterns of fall armyworm (Lepidoptera: Noctuidae) in the United States from mitochondrial haplotypes. Ecology and Evolution, 2(7), 1458-1467. https://doi.org/10.1002/ece3.268

Nagoshi, R. N., Fleischer, S., Meagher, R. L., Hay-Roe, M., Khan, A., Murúa, M. R., ... Westbrook, J. (2017). Fall armyworm migration across the Lesser Antilles and the potential for genetic exchanges between North and South American populations. PLoS ONE, 12(2). https://doi.org/10.1371/journal.pone.0171743

Pastrana, J. A. (2004). Los Lepidópteros Argentinos: Sus plantas hospedadoras y otros substratos alimenticios (p. 334). Sociedad Entomológica Argentina, Buenos Aires.

Pencoe, N. L., \& Martin, P. B. (1982). Fall armyworm (Lepidoptera: Noctuidae) larval development and adult fecundity on five grass hosts. Environmental Entomology, 11(3), 720-723. https://doi.org/10.1093/ ee/11.3.720

Pitre, H. N., \& Hogg, D. B. (1983). Development of the fall armyworm on cotton, soybean and corn. Journal of the Georgia Entomological Society, 18, 182-187.

Pogue, G. M. (2002). A world revision of the genus Spodoptera Guenée (Lepidoptera: Noctuidae). Philadelphia: American Entomological Society, 43, 1-202.

Rizzo, H. F., \& La Rossa, F. R. (1992). Aspectos morfológicos y biológicos de la "oruga militar tardia" (Spodoptera frugiperda (J. E. Smith) (Lep.: Noctuidae). Revista de la Facultad de Agronomía. Universidad de Buenos Aires, 13, 2-3.

Rogers, C. E., \& Marti Jr., O. G. (1994). Reproductive potential of once mated moths of the fall armyworm (Lepidoptera: Noctuidae). The Florida Entomologist, 77, 402-410. https://doi.org/10.2307/3495694

Rogers, C. E., \& Marti Jr., O. G. (1997). Once-mated beet armyworm (Lepidoptera: Noctuidae): Effects of age at mating on fecundity, fertility, and longevity. Environmental Entomology, 26(3), 585-590. https://doi.org/ 10.1093/ee/26.3.585

Sadek, M. M. (2001). Polyandry in field-collected Spodoptera littoralis moths and laboratory assessment of the effects of male mating history. Entomologia Experimentalis et Applicata, 98(2), 165-172. https://doi.org/ 10.1046/j.1570-7458.2001.00771.x

Santos, L. M., Redaelli, L. R., Diefenbach, L. M. G., \& Efrom, C. F. S. (2004). Fertility and longevity of Spodoptera frugiperda (J. E. Smith) (Lepidoptera: Noctuidae) in corn genotypes. Ciência Rural, 34(2), 345-350. https://doi.org/10.1590/S0103-84782004000200002

Sekul, A. A., \& Sparks, A. N. (1967). Sex pheromone of the fall armyworm moth: isolation, identification, and synthesis. Journal of Economic Entomology, 60(5), 1270-1272. https://doi.org/10.1093/jee/60.5.1270.

Silva, A. G. A., Gonçalves, C. R., Galvão, D. M., Gonçalves, A. J. L., Gomes, J. Silva, M. N., \& Simoni, L. (1968). Quarto catálogo dos insetos que vivem nas plantas do Brasil: Seus parasitos e predadores, Parte II, tomo 1o, Insetos, hospedeiros e inimigos naturais. Ministério da Agricultura, Rio de Janeiro.

Silva, C. S. B., \& Parra, J. R. P. (2013). New method for rearing Spodoptera frugiperda in laboratory shows that larval cannibalism is not obligatory. Revista Brasileira de Entomologia, 57(3), 347-349. https://doi.org/ $10.1590 / \mathrm{S} 0085-56262013005000029$

Silveira-Neto, S., Nakano, O., Barbin, D., \& Villa Nova, N. A. (1976). Manual de ecologia dos insetos. São Paulo, SP: Editora Agronômica Ceres.

Simmons, A. M., \& Marti Jr., G. O. (1992). Mating by the fall armyworm (Lepidoptera: Noctuidae): Frequency, duration, and effect of temperature. Environmental Entomology, 21(2), 371-375. https://doi.org/10.1093/ ee/21.2.371

Specht, A., \& Roque-Specht, V. F. (2016). Immature stages of Spodoptera cosmioides (Lepidoptera: Noctuidae): developmental parameters and host plants. Revista Zoologia, 33(4), e20160053. https://doi.org/10.1590/ S1984-4689zool-20160053

Specht, A., Montezano, D. G., Sosa-Gómez, D. R., Paula-Moraes, S. V., Roque-Specht, V. F., \& Barros, N. M. (2016). Reproductive potential of Spodoptera eridania (Stoll) (Lepidoptera: Noctuidae) in the laboratory: 
effect of multiple couples and the size. Brazilian Journal of Biology, 76(2), 526-530. https://doi.org/ 10.1590/1519-6984.23114

Tisdale, R. A., \& Sappington, T. W. (2001). Realized and potential fecundity, egg fertility, and longevity of laboratory-reared female beet armyworm (Lepidoptera: Noctuidae) under different adult diet regimes. Annals of the Entomological Society of America, 94(3), 415-419. https://doi.org/10.1603/0013-8746 (2001)094[0415:RAPFEF]2.0.CO;2

Tumlinson, J. H., Mitchell, E. R., Teal, P. E. A., Heath, R. R., \& Mengelkoch, L. J. (1986). Sex pheromone of fall armyworm, Spodoptera frugiperda (J. E. Smith). Identification of components critical to attraction in the field. Journal of Chemical Ecology, 12(9), 1909-1926. https://doi.org/10.1007/BF01041855

Vázquez, G. M., Carrillo, S. J. L., Granados, R. G., \& García, C. M. (1975). Cria massiva del gusano cogollero Spodoptera frugiperda (J. E. Smith) y variación de infestaciones artificiales sobre maíz en el campo. Agrociencia, 22(4), 3-13.

Veloso, V. R. S., Parra, J. R. P., \& Nakano, O. (1983). Dados biológicos comparativos de Spodoptera frugiperda (J. E. Smith, 1797) (Lepidoptera: Noctuidae) em algodoeiro e milho. Pesquisa Agropecuária Tropical, 12, 127-140.

\section{Copyrights}

Copyright for this article is retained by the author(s), with first publication rights granted to the journal.

This is an open-access article distributed under the terms and conditions of the Creative Commons Attribution license (http://creativecommons.org/licenses/by/4.0/). 